\title{
THE FINE-GRAINED PLIO-PLEISTOCENE DEPOSITS IN ACHAIA - GREECE AND THEIR DISTINCTION IN CHARACTERISTIC GEOTECHNICAL UNITS
}

\author{
Kouki A. ${ }^{1}$, Rozos D. ${ }^{2}$ \\ ${ }^{1}$ Ministry of Public Works, EYDE - Motorway PATHE, Alexandras Av. 205, Athens, Greece, \\ kouki.nassia@gmail.com \\ ${ }^{2}$ National Technical University of Athens, School of Mining and Metallurgical Engineering, Laboratory of \\ Engineering Geology and Hydrogeology, 9, Heroon Polytechniou Str 157 80, Zografou (Athens) Greece, \\ rozos@metal.ntua.gr
}

\begin{abstract}
The fine grained Plio-Pleistocene sediments encountered along the Patras Ring Road project (PRR) were distinguished into two lithological units, the Upper Geotechnical and the Lower Geotechnical Unit, based on the detailed engineering geological-geotechnical mapping, at a scale of 1:5000, on fieldwork, as well as on data gained from the boreholes drilled during the design and construction of the project. These units are distinguishable, stratigraphically successive and present basic differences in lithological composition, consistency and permeability and therefore different mechanical behaviour during construction .
\end{abstract}

Key words: Patras ring road, Pliopleistocene sediments, fine grained, Upper Geotechnical unit, Lower Geotechnical unit.

\section{Introduction}

By taking into account site investigation data for Patras Ring Road (RPP) the findings from the construction of the project (Efpalinos Techniki, 1996, 1997, Edafomechaniki 1995, 1997 \& 1998, Kastor, 1998, 1999, OMETE 1998 and Pangea, 1998, 1999 \& 2001), other studies (Attewell, 1993, Rozos, 1989, Koukis \& Rozos, 1990, Tsiambaos \& Koukis1990, Koukis et al.,2005), and the results of our research, an inceptive suspicion was confirmed. This was that the fine-grained facies of the Pliopleistocene sediments, in which the project was mainly hospitalized, are formulated in two distinguishable and successive units: (a) the Upper Geotechnical unit and (b) the Lower Geotechnical unit (Kouki, 2006). An intermediate Transitional zone of small thickness can be separated at places, between these two units.

It is pointed out that the Lower unit is not easily recognized on the surface, since it is stratigrafically covered by the Upper one. Its presence was firstly acquainted during the excavation of the underground works, when its different geotechnical behavior was realized. Thus, it was mainly sought in deep gorges of the wider area, during the field work. It has to be mentioned here that the presence of these distinguishable geotechnical units was not evaluated during the geological - geotechnical investigations for the design of the PRR.

The field characteristics of these units are described in detail in the engineering geological - geotechnical map at a scale of 1:5000, that was compiled for the study area (Kouki, 2006, Kouki and Rozos, 2010), while in Photos 1, 2 and 3, their presence is documented. 

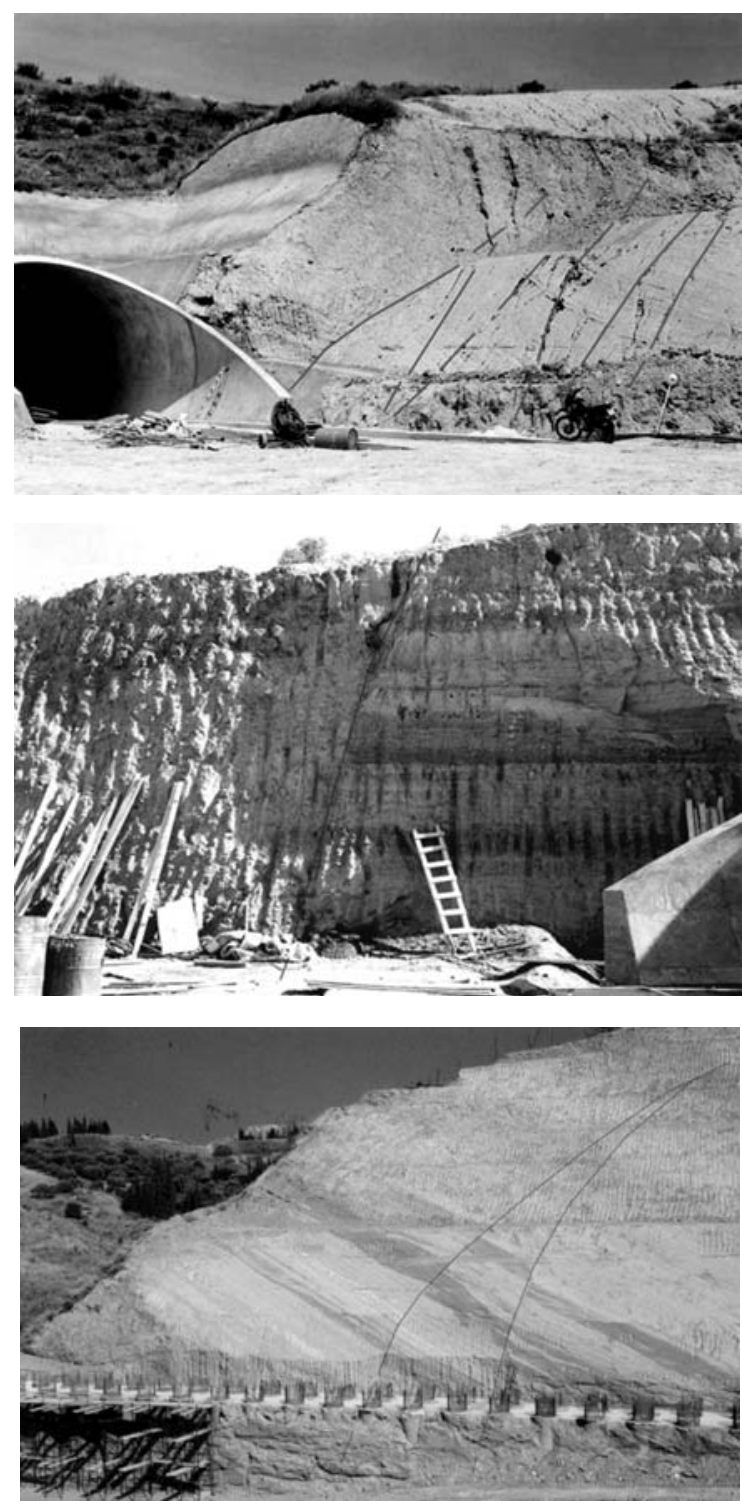

Photo 1: Southern portal of tunnel SB (left branch). The two units (Upper and Lower ones) are distinguished, due to color and structure. Their continuity is interrupted by faults that considerably change dipping.

Photo 2: Northern portal of tunnel SA (left branch). The Pliopleistocene sediments are characterized by almost horizontal dipping. The Lower unit, grayish blue in color, is progressively changing, through the transitional zone, into the light gray Upper unit. In the centre of the Figure a normal fault is presented, that has substantially change the previous sequence and thus the slope (in the left hand site of the figure) is only occupied by sediments of the Upper unit.

Photo 3: Characteristic stratigraphic sequence of the fine-grained facies of Pliopleistocene sediments, with the grayish blue deeper horizons (Lower unit), that progressively is developing in the grayish brown transition zone and the light gray horizons of the Upper unit.

\section{Evaluation of the data from the geotechnical study}

Beyond the field work findings, further investigation regarding the segregation of the above units in the fine grained Pliopleistocene sediments, was also facilitated, by the data from boreholes drilled for the design of Patras Ring Road (Kastor, 1998, Edafomechaniki,1995,1997 \& 1998, Pangea 1998, 1999). In every $\log$ of the 169 boreholes examined, there was an effort to group the various litho-facies that were recorded, in order to find out whether these distinguishable Upper and Lower units do exist in the wider study area or whether this is a unified formation with small differentiations. For that reason, the field observations and description of borehole logs, such as color, composition, cohesiveness, were basically examined along with in situ tests, such as SPT, and laboratory tests (i.e. grain size distribution and Atterberg limits). Characteristic logging of a geotechnical borehole is given in Figure 1. 


\section{The compilation of the geotechnical cross sections along the two branches of Patras ring road}

For better understanding of the Upper and Lower units, the geotechnical cross sections for both branches (right and left) of Patras ring road were drawn (Figures 2 and 3). For the compilation of these, the topographic sections from the design of Patras Ring Road were used, supplemented with both the surface mapping, engineering geological and tectonic data, as well as those derived from borehole logs.

Thus, the segregation of the units was achieved with accuracy and the thickness was estimated ranging for the Upper unit from 2 to $37 \mathrm{~m}$, for the Transitional zone up to $8 \mathrm{~m}$, while the Lower unit has quite a significant thickness of over $60 \mathrm{~m}$.

Additionally, from the above sections it is shown that in the region of the Archaeological site of the area (Tunnel S1-Cut and Cover - Tunnel SG) and southwards, clayey marly horizons with coarsegrained materials of Pliopleistocene sediments were mapped, overlying the Upper unit, with a thickness fluctuating from 10 to $40 \mathrm{~m}$. Also, the Cut and Cover in Mpozaitika site, was opened in Dilluvial conglomerates.

Concerning the problems related to the Upper unit during construction, these are mainly due to the frequent alternation of beds with different lithological composition, such as brownish yellow to brownish gray clayey marls, sandy marls, sandy silts - sands, sandstones and conglomerates. The sandstones and conglomerates present differences in cohesiveness, fracturing and weathering, as well as in permeability. Thus, the sandy layers - sandstones are usually saturated and can create confined aquifers of small capacity, which can cause serious problems during the construction of technical works. Moreover, the formations of the Upper unit usually create thick weathering and fracturing zones, which lead to instability problems, especially in the case of tunnels with overburden of small thickness.

On the contrary, the Lower unit (usually stiff marls to clayey marls with thin coarse grained intercalations) is practically considered as impermeable and cohesive formation, which generally demonstrates uniform and very good geomechanical behaviour during the construction of underground works. It is pointed out that, this formation is distinguished for its dense bedding, which at places becomes foliar. This positively acts in conditions of regular moisture content (increased cohesion) and negatively when this formation is saturated, where the absorbed water in their structure leads progressively to collapse. This is mainly observed when the Lower unit formations are constantly watered in depth from overlying permeable layers of the Upper unit, as well as along structural discontinuities (faults and fractures).

\section{Conclusions-Results}

Based on the evaluation of all collected data, the following conclusions can be made:

- The discrimination of individual units was achieved in all borehole logs examined. Moreover, in some of the logs the limits between the units are not clear, due to the presence of an intermediate transitional zone of small thickness.

- The formations of Lower unit, as well as those of the transitional zone present high cohesiveness and characteristic bedding with frequent alternations of layers, which makes the discontinuities intersecting the formation visible. So, normal and reversed faults were observed due to tensile and compressive stresses on these sediments. On the contrary, these characteristics do not exist in the 


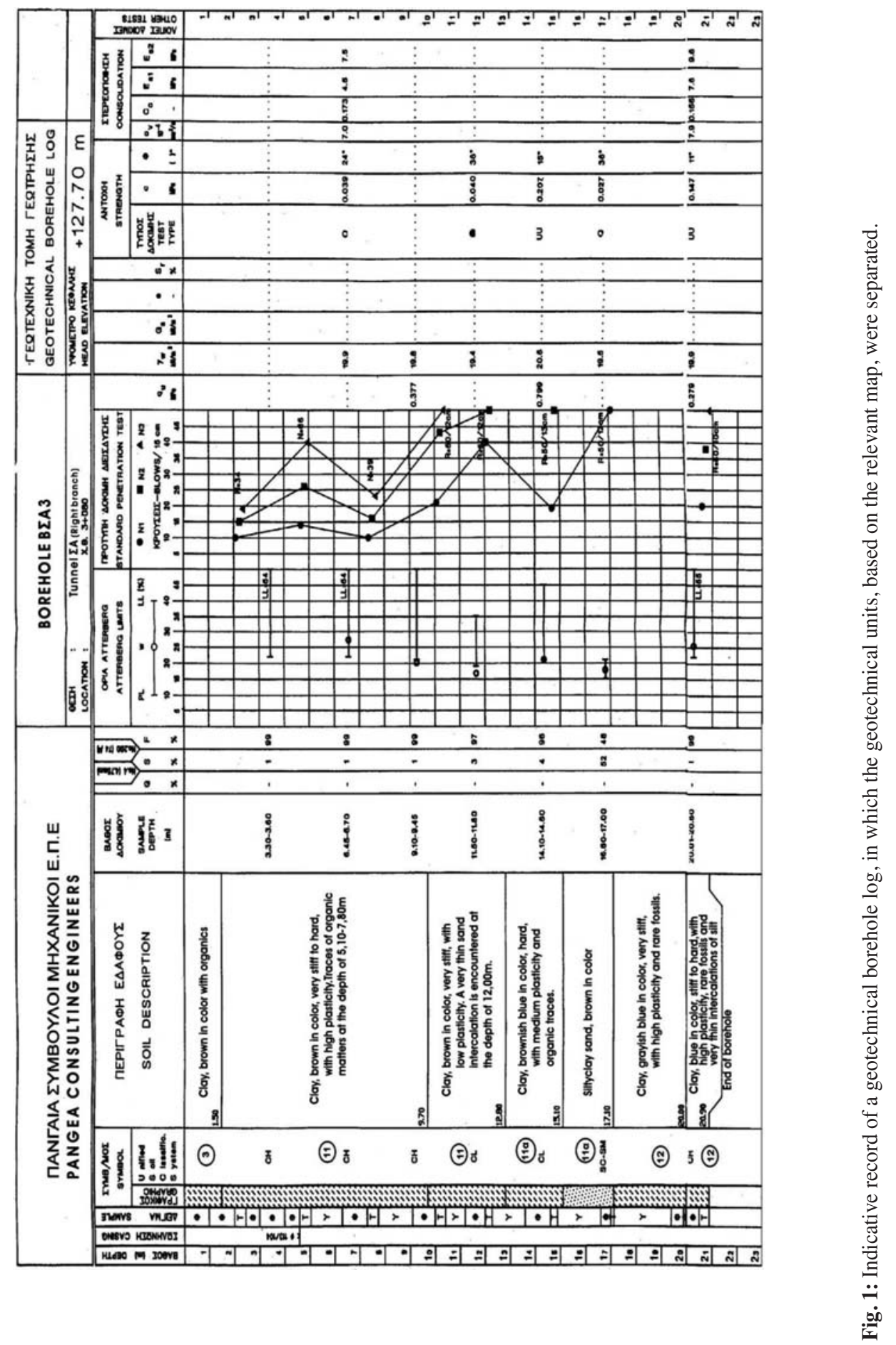




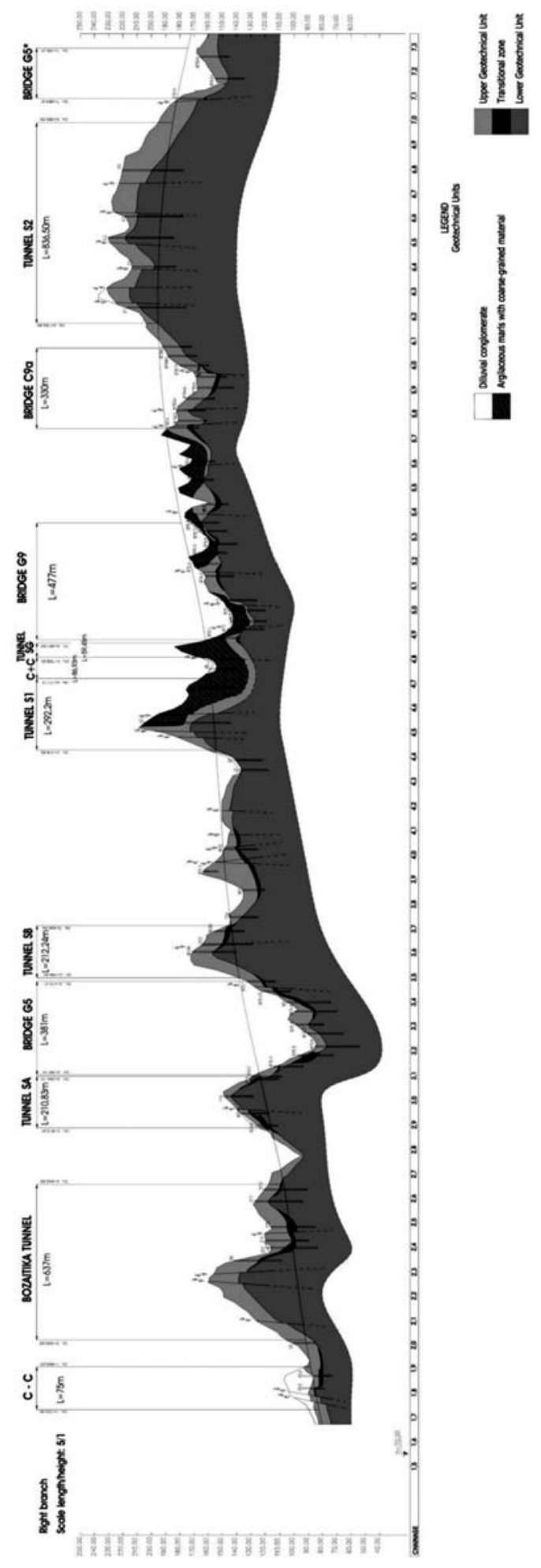

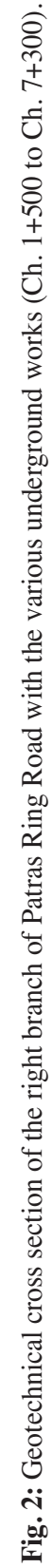

XLIII, No 3 - 1181 


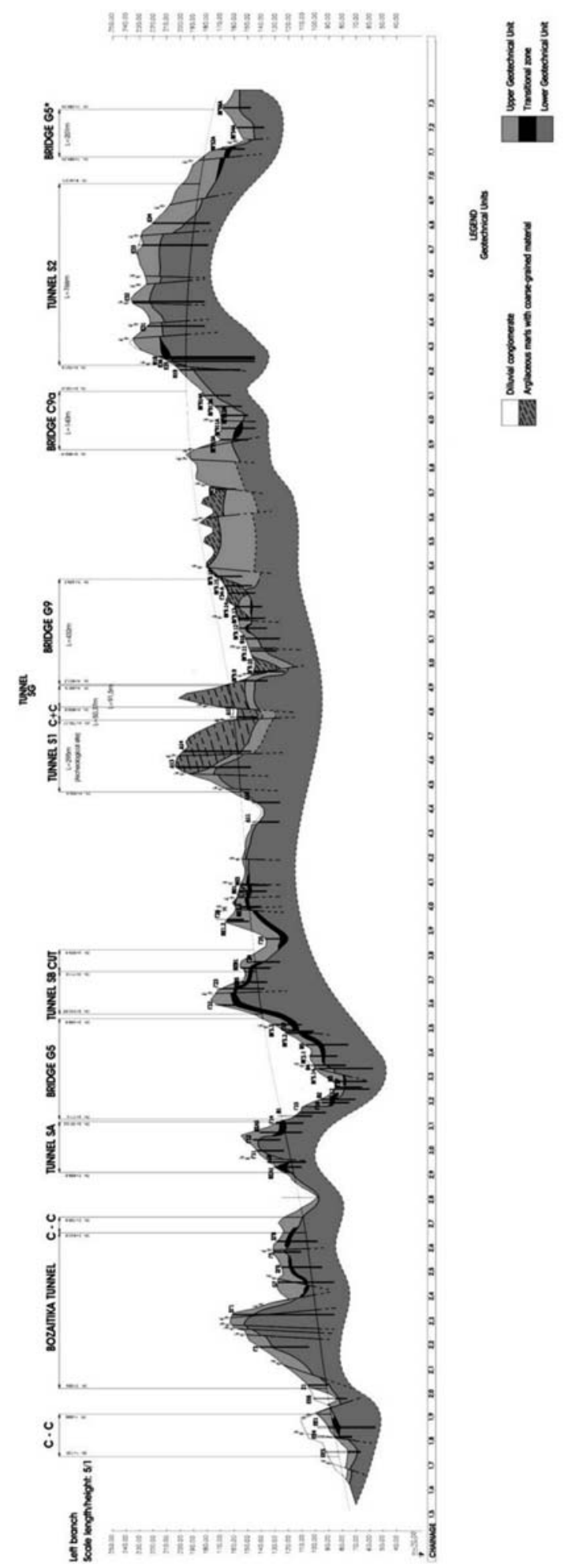

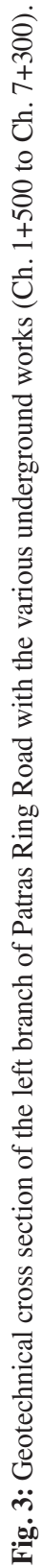

XLIII, No $3-1182$ 
Upper unit, due to its lithology and cohesiveness.

- There was an absolute match of the surface mapping observations with data from boreholes, which confirmed the presence and the segregation of the two units. Thus, this discrimination reflects both the surficial and the in-depth growth of the units, facilitating the confrontation of the geotechnical problems, which can arise during construction of technical works.

Based on all the above peculiarities, it is obvious that every further research for technical works under design should be focused on a detailed imprinting of these formations, both surficialy and indepth. This will also enable the evaluation of their individual characteristics. With the confirmation and acceptance of this consideration and based on the fact that the Pliopleistocene sediments and in general the Neogene sediments in many regions of the Greek territory present an equivalent structure (in terms of lithology and stratigraphic sequence), it would be useful the geological and geotechnical research to be conducted towards this direction from the initial stages of the design. In this way the potential geotechnical problems will be pointed out at the early stage of the design, resulting to most optimal planning of technical works.

\section{References}

Attewell, P.B. 1993. Tunnelling and site investigation. Proc. of Int. Symposium on Geotechnical Engineering of Hard Soils - Soft Rocks, Athens. Balkema Rotterdam.

EFPALINOS TECHNIKI, (1996). Patras Ring Road (RPP). Final design of Mpozaitika tunnel. Unpublished reports, Athens.

EDAFOMECHANIKI (1995, 1997, 1998). Patras Ring Road (RPP). Geotechnical investigations for the twin tunnels in Mpozaitika site "Agia Barbara". Unpublished reports, Athens.

KASTOR (1998, 1999). Patras Ring Road (RPP). Geotechnical investigation and design of twin tunnels in Archaeological and Girokomion sites. Unpublished reports, Athens.

Koukis, G., Rozos, D., 1990. Geotechnical properties of Neogene sediments of the NW Peloponnesus Greece. Proc 6th Int. IAEG Congress, Amsterdam p405-412. Balkema, Rotterdam.

Koukis, G., Sadatakakis, N., Tsiambaos, G. and Katrivesis, N., 2005. Engineering Geological approach to the evaluation of seismic risk in metropolitan regions: case study of Patras, Greece. Bull. of Eng. Geol. and Environment, 64:p219-235.

Kouki A. 2006. Engineering geological - geotechnical parameters and mechanical behavior of hard soils and soft rocks in the design of underground works. Unpublished PhD Thesis (in Greek, with extensive summary in English). University of Patras, p.414.

Kouki, A. and Rozos, D. 2010. Engineering geological - geotechnical conditions in the wider area of Patras Ring - Road. Compilation of the relevant map at a scale of 1:5000. Bulletin of the Geological Society of Greece - 12th International Congress, Patras, Greece (in press).

OMETE (1998). Patras Ring Road (RPP). Primary support design of the twin tunnels in Archaeological and Girokomion sites. Unpublished reports, Athens.

PANGEA (1998,1999, 2001). Patras Ring Road (RPP). Primary support design of the twin tunnels SA, SB and SG. Unpublished reports, Athens.

Rozos, D. 1998. Engineering Geological conditions in Achaia County. Geomechanical characteristics of Plio-pleistocene sediments. PhD Thesis (in Greek, with extensive summary in English)., University of Patras, 453p. Rio Patras.

Tsiambaos, G., Koukis, G., 1990. Geotechnical conditions of the Iraklion city, Crete. Proc 6th Int. IAEG Congress, Amsterdam V3, p2037-2042. Balkema, Rotterdam. 
ENGINEERING GEOLOGICAL - GEOTECHNICAL CONDITIONS IN PATRAS RING ROAD WIDER AREA, GREECE. COMPILATION OF THE RELEVANT MAP AT SCALE OF 1:5000

\author{
Kouki A. ${ }^{1}$, Rozos D. ${ }^{2}$ \\ ${ }^{1}$ Ministry of Public Works, EYDE - Motorway PATHE, Alexandras Av. 205, Athens, Greece, \\ kouki.nassia@gmail.com \\ ${ }^{2}$ National Technical University of Athens, School of Mining and Metallurgical Engineering, Laboratory of \\ Engineering Geology and Hydrogeology, 9, Heroon Polytechniou Str 157 80, Zografou (Athens) Greece, \\ rozos@metal.ntua.gr
}

\begin{abstract}
In order to evaluate the geotechnical parameters and the mechanical behavior of the Plio-Pleistocene sediments encountered along the Patras Ring Road, the lithology, the structure, the hydrogeological regime, the hydro meteorological data and the seismicity of the wider area were firstly examined.

More specifically, the morphological relief map and the map of slope inclination were compiled on the digitized topographic map, along with the engineering geological - geotechnical map of the area, at a scale of 1:5000, where the distinction of the Plio-Pleistocene deposits is shown. This distinction was based on geological criteria, as far as lithology and stratigraphic sequence are concerned, as well as on engineering geological - geotechnical criteria.
\end{abstract}

Key words: Patras Ring Road, Pliopleistocene sediments, Geotechnical units, Eng. GeologicalGeotechnical mapping.

\title{
1. Introduction
}

Regarding the mechanical behavior of the geological formations that belong to the category of "Hard Soils - Soft Rocks", the Plio-Pleistocene sediments of Achaia were studied, focusing on the area of Patras Ring Road (Kouki, 2006). The above formations have also been studied in the past, respecting their geological, engineering geological and hydrogeological features, (Doutsos et al, 1987, 1988; Rozos, 1989; Kontopoulos \& Zelilidis, 1992, 1997; Voudouris, 1995; Tsiambaos et al, 1997; Koukis et al, 2005, 2007).

The investigation of these formations is of great importance, as there was no previous experience on tunneling through them. Therefore, data from the geological and geotechnical reports for the project were used, along with field investigation and the detailed engineering geological and geotechnical mapping. All data helped to have a general view and a good approach of these formations and led to the division of their fine grained facies into two separate Geotechnical Units, the Upper and the Lower one. These Units are characterized by their different lithology, mineralogical composition, physicomechanical features and mechanical behavior. 


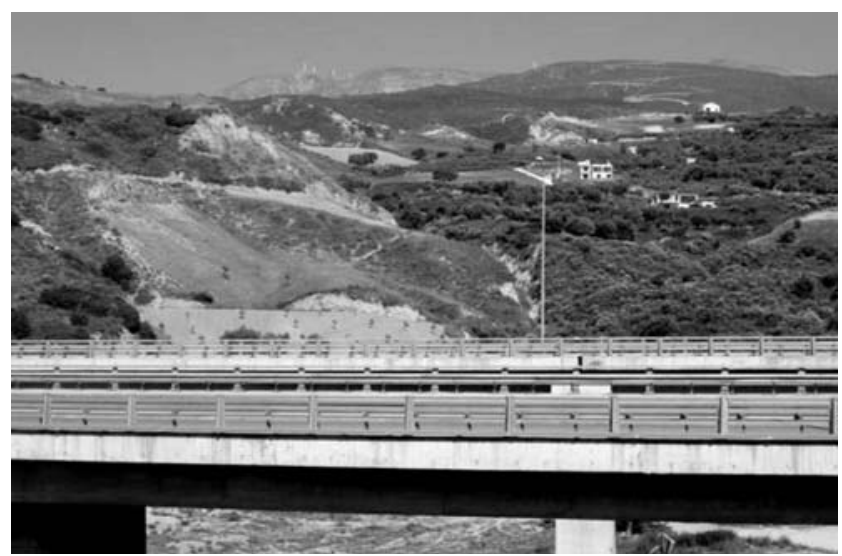

Photo 1: General view of the PlioPleistocene sediments in the hilly area behind the bridge $\Gamma 5$. The Alpine formations are visible in the upper part of the photo (Panahaikon Mountain).

\section{Location and geomorphologic setting of the study area}

The wider study area is located at the NW part of Achaia County, with an average elevation of $600 \mathrm{~m}$ and an average slope inclination between 6.0 and $15.5 \%$. The morphological relief is a result of combined action of lithology, tectonism, weathering and erosion processes. Especially, the present morphology of the area has been formed by post-Alpine tectonic movements, as well as the evolution of the various morphological cycles, that continue to the present time.

Geologically, the wider area consists, from the west to the east, of formations of Gavrobo-Tripoli and Pindos Geotectonic zones. The hilly areas that surround the high mountains consist of post-alpine sediments. The summits of these hills are usually round-shaped and not sharp-shaped, indicating intense erosion processes (Photo 1).

Hydrographic network has been developed as a result of combination of lithological features, tectonics and morphology, as well as climate. It is mainly oriented along main faults zones.

The engineering geological map of Figure 1 shows, in more detail, the geological conditions along the alignment. It can be concluded that the Ring Road is mainly founded on Plio-pleistocene sediments, coarse and fine - grained and less on Quaternary deposits. The later can be divided into mixed-phase loose, loose mainly coarse-grained, coherent coarse-grained and mixed-phase coherent formations.

After revising and processing of aerial photos and field investigation it was concluded that the main faulting directions are NE-SW and NW-SE.

Due to the tectonic activity, the area is characterized by intense seismicity. The most recent earthquakes of the broader region are the earthquake of Alkyonides in 1981 (Ms=6.7) and of Aigion in 1995 (Ms=6.2). These magnitudes are relatively high and since they are close to the study area, it is possible that future earthquakes can cause there damages (Sokos, 1998). It is noted that Achaia belongs, according to the Greek Seismic Code (NEAK, 2004) to the zone of seismic hazard II $(\mathrm{a}=0.24 \mathrm{~g})$

\section{Hydro meteorological data - Hydrogeological regime}

For the investigation of distribution and fluctuation of climatic parameters, meteorological data from the National Meteorological Service were used and especially data from Patra's station, covering the period 1931-2004. 


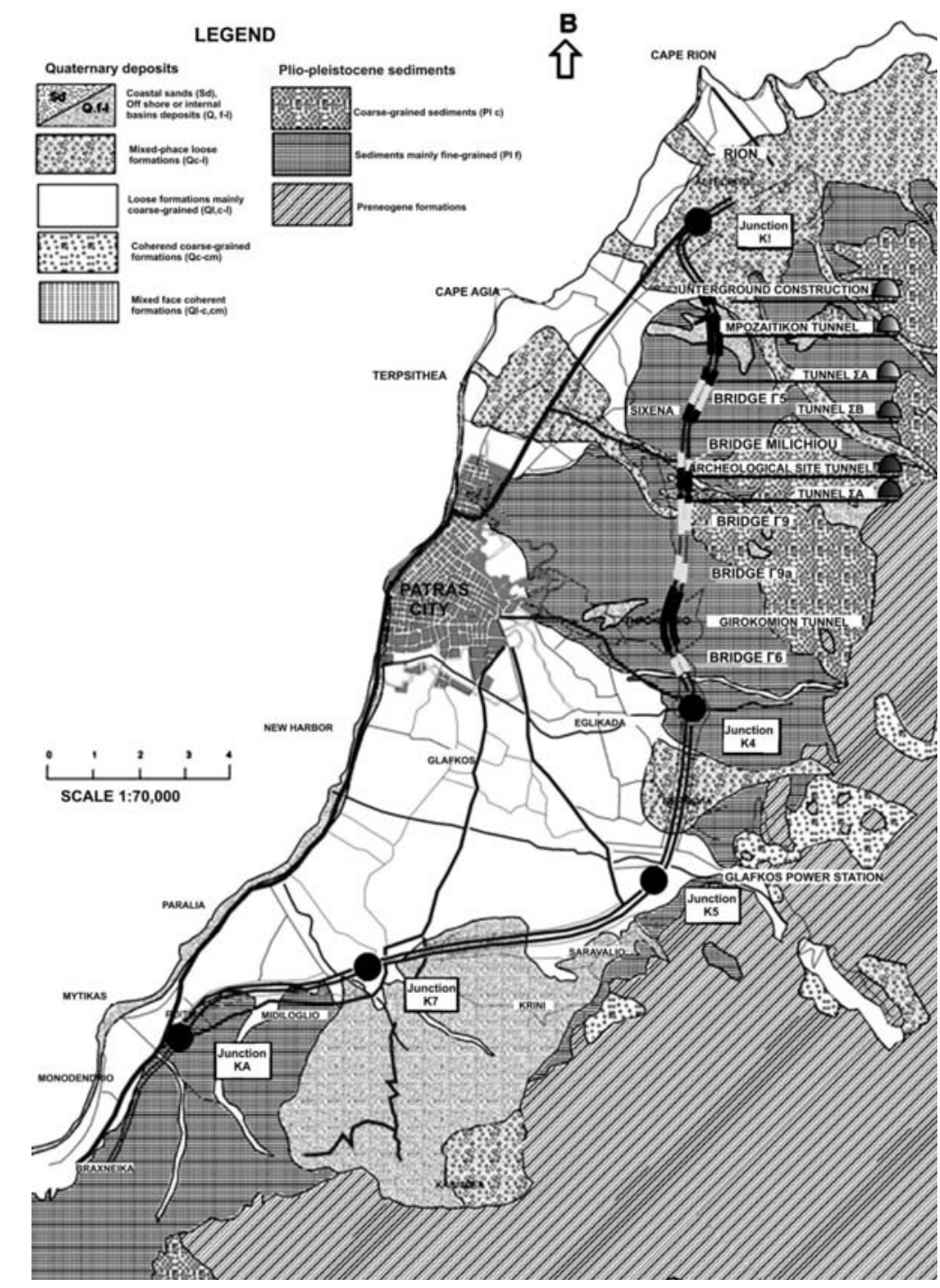

Fig. 1: Engineering geological map of Patras Ring Road wider area.

The lower temperatures dominate during the winter $\left(10,6^{\circ} \mathrm{C}\right)$ and the higher during the summer $\left(25.8^{\circ} \mathrm{C}\right)$, while autumn temperatures are about three degrees higher than those of spring period.

Annual rainfall heights show large fluctuation from $350 \mathrm{~mm}$ in dry periods (e.g. 2000) to $1350 \mathrm{mmm}$ during wet periods, such as 1993 or 2003 . Based on these data and the fact that these geological formations are susceptible to erosion, it is concluded that it is the combined effect of thermal weathering and mechanical erosion that causes further loosening and strength reduction. This leads to locally unstable conditions and the manifestation of landslides.

From the hydrogeological point of view, the geological formations were divided into different categories, according to their estimated permeability. They were classified as pervious (e.g. loose Qua- 
ternary deposits), permeable with secondary porosity (Karstic limestones), semi-pervious (Pliopleistocene sediments, coarse-grained, Plc and fine-grained, Plf), and impervious (Flysch and Cherts).

According to the above and by taking into account the possible effects on the Ring Road construction, special attention was given to the Plio-Pleistocene sediments, because the majority of underground excavations took place in these formations. In Plc formations the lithology and stratigraphy result to the creation of aquifers and springs of medium to high discharge, located along the contacts of pervious and impervious beds. In Plf sediments, successive confined or perched aquifers are formed, usually inside coarse lenses. These conditions caused, in some cases, water flow during underground excavations, but the typical clayey and marly facies of these sediments are considered as impervious formations.

Furthermore, after analysis of piezometric curves in the lowland areas it was concluded that even in the most permeable alluvial deposits the water table was very low, so groundwater could not affect the Ring Road.

\section{Engineering Geological - Geotechnical mapping at 1:5000 scale}

After scanning of the hardcopy map, digitizing was performed in GIS environment. Digital data, such as elevation contours every $20 \mathrm{~m}$, rivers, inhabited areas, as well as Ring Road alignment was classified in thematic layers. All data were projected to the Greek Grid (EГ $\Sigma \mathrm{A} 87)$.

Based on the alignment final design drawings two cross-sections along the road axis were drawn at a scale of 1:5000 (length) and 1:1000 (height) that correspond to the left and right branch (Kouki, 2006; Kouki \& Rozos, 2010).

By using the digitized maps, Digital Elevation Models and slope maps were created. These maps show that the Road crosses areas with fully developed hydrographic network, with main directions perpendicular to the alignment. The elevation ranges from 20 to $240 \mathrm{~m}$. The greater part of the road crosses relatively plain areas (inclined up to $10^{\circ}$ ), while the underground works are located in areas of intense relief (inclination from $10^{\circ}$ up to more than $30^{\circ}$ ).

From geological point of view, these Plio-pleistocene sediments have been so far presented in the IGME Geological Sheets of Nafpaktos, Patras and Chalandritsa at a scale of 1:50,000 (IGME, 1971, 1980, 1984), while their engineering geological properties are described by Rozos (1989) and Kouki (2006). The geological and geotechnical studies that were conducted before and during the project of Patras Ring Road did not further divide these sediments. Their geotechnical assessment was based on the results of soil classification tests and data from numerous boreholes, drilled for this purpose.

The present study was focused on the Ring Road wider area, first of all through the engineering geological mapping, using topographical maps at a scale of 1:5000. Previous data was taken under consideration (Rozos, 1989, Koukis and Rozos, 1990; Rozos et al, 2006), as well as data from the 169 boreholes drilled along the project (Kouki, 2006). Mapping was assisted by aerial-photo interpretation, using recent (2002) large-scale aerial photos (at a scale of 1:5000).

The legend of the map provides a rather comprehensive description of the geological formations (Kouki, 2006), as far as lithology, sedimentation type, distribution of different soil facies, degree of digenesis and cohesiveness, type of soil matrix, color, permeability, as well as fracturing and weathering degree are concerned. Based on the above geological and geotechnical criteria. and the experience gained from the construction of the project, there was a distinction of the fine-grained facies 


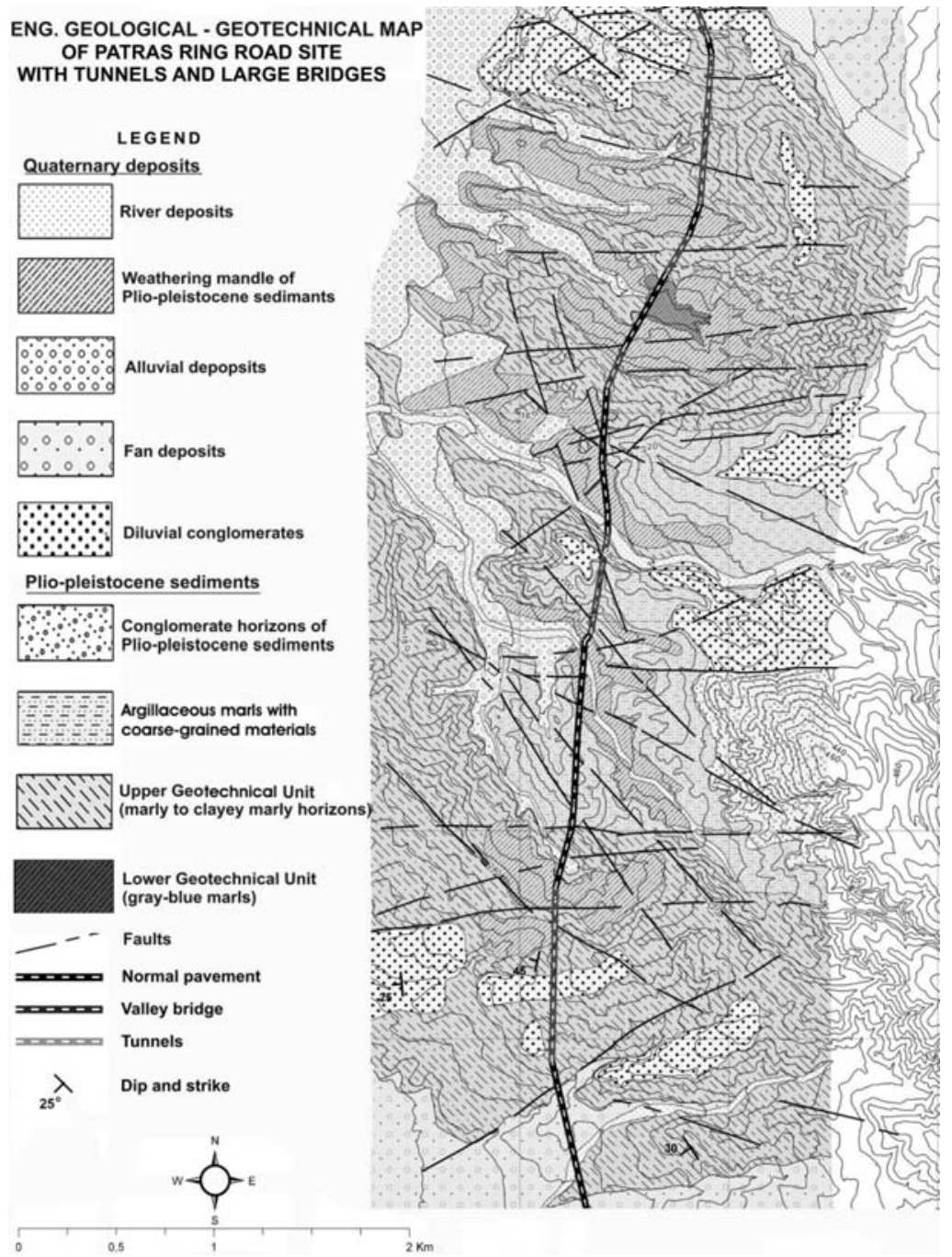

Fig. 2. Engineering Geological - Geotechnical map of Patras Ring Road site.

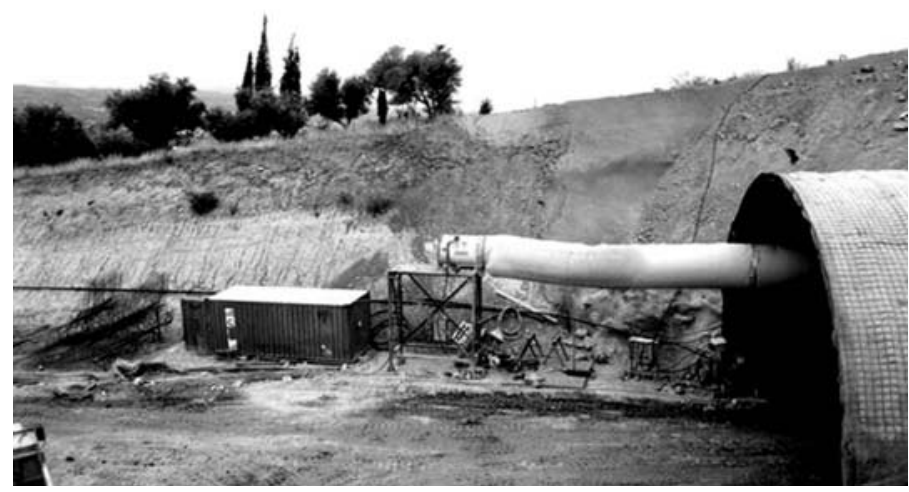

Photo 2: South part of Girokomion tunnel $(\Sigma 2)$, right branch. The Diluvial conglomerates cover with unconformity the Upper Geotechnical unit. 


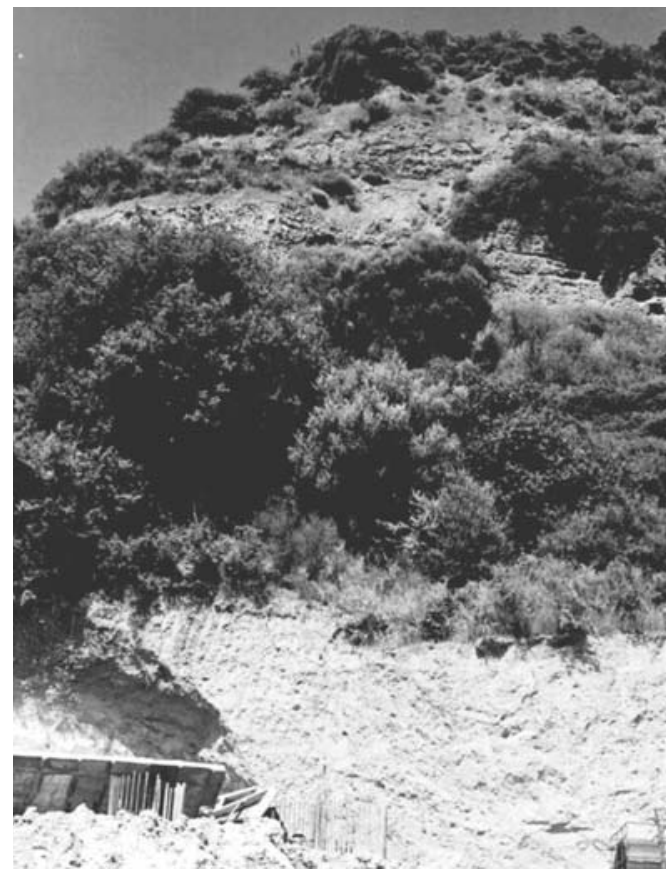

Photo 3: Exit of SG tunnel. Stratigraphic column of the Upper Geotechnical Unit at the base, over lied by conglomerates with distinct bedding (Unit of Argillaceous marls with coarse-grained material).

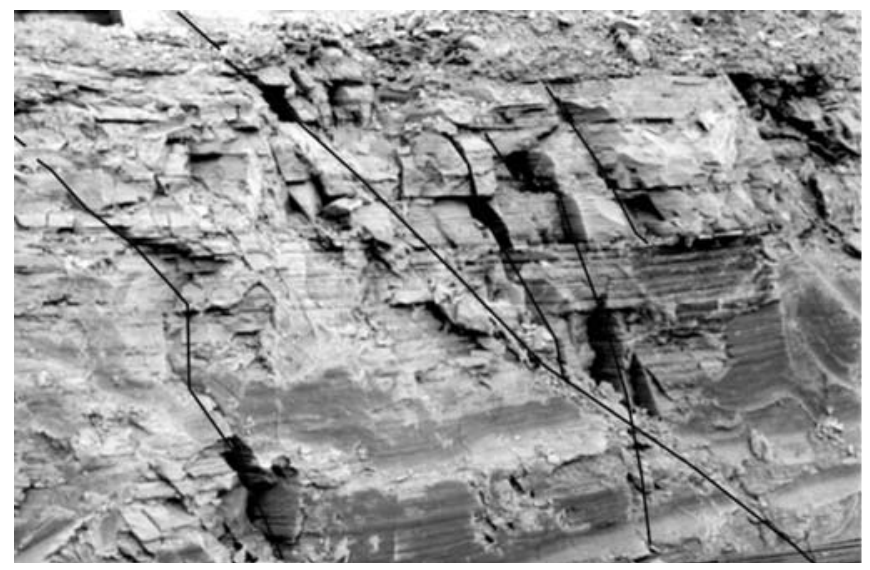

Photo 4: Gray-blue marls horizons of the Lower Geotechnical unit at a slope near a Cut \& Cover at the exit of Bozaitika tunnel. The almost horizontal layers and the high fracturing of these weak rocks are shown. The fracturing is due to joint sets almost vertical to the bedding.

of the Plio-pleistocene sediments into two geotechnical units, the Upper and Lower one. In Figure 2 , a simplified version of the engineering geological - geotechnical map is given.

It is concluded that the project is mainly hosted in the fine-grained Plio-Pleistocene sediments (Upper and Lower Geotechnical units). Also, a part of it was constructed in the argillaceous marls with coarse grained materials, while the first Cut and Cover of the project in the diluvial conglomerates (Photos 2, 3 and 4).

It is pointed out that the Lower Geotechnical unit appears only in a few places and it would not have been recorded unless it was met during underground excavations. It should be mentioned, that dur- 
ing the geological and geotechnical investigations prior to construction, the Plio-Pleistocene sediments were studied geotechnically as a whole, without any further subdivision.

More specifically, the Upper Geotechnical unit is characterized by frequent alternations of brownyellow to brown-gray clayey marls, sandy marls, sandy silts, sands and sandstones. The Lower unit consists of beds of gray-blue marls, usually stiff, clayey marls with some sparse coarser phases, mainly sands or sandy silts. Problems that are connected to the Upper unit can be attributed to this alternation of horizons with different lithology, cohesiveness, fracturing and weathering degree, as well as permeability. On the contrary, the Lower unit is considered to be an impervious and very cohesive formation, with homogenous and generally very good mechanical behavior during underground excavations.

\section{Conclusions - Results}

This paper studies the Plio-Pleistocene sediments in the area of Patras Ring Road in Achaia, Greece. It aims to a better knowledge of their mechanical behavior and response during the construction of engineering works of large scale and particularly underground ones.

The area that these formations cover is generally hilly, while the mountainous areas that surround them consist of Alpine bedrock rocks, (i.e. formations of Olonos - Pindos and Gavrobo -Tripoli Geotectonic Zones).

The investigation of these Plio-Pleistocene sediments, which are geomechanically classified as "Hard Soils-Soft Rocks", was based on their surface appearance and on samples from numerous boreholes. This resulted to the division of their fine-grained facies into two separate Geotechnical units, the Upper and the Lower one, with a Transitional zone between them at places. Both units are characterized by their different lithology, mineralogical composition and physicomechanical properties. It is noted that for the design of Patras Ring Road, the two units, Upper and Lower one, were not dealt as distinct formations with different geotechnical behavior, but were considered as a uniform one.

Aiming to a better understanding of the extent of both units and the importance of their distinction for the design of underground works, engineering geological mapping at a 1:5000 scale was performed. Their vertical extent was presented in two geotechnical cross-sections along the alignment of each branch, including faults and the Transitional zone. The Upper unit formations can cause problems during construction, due to their frequent alternation of different lithological types, fracturing, weathering, as well as due to their locally increased permeability. On the contrary, the Lower unit is an impervious and very cohesive formation, with very good behavior during tunnel excavation and construction. The problems related to this unit are basically located in areas where the formations are saturated (mainly along fault zones), which leads progressively to the loosening of their structure.

\section{References}

Doutsos, T., Kontopoulos, N., Frydas, D. 1987. Neotectonic evolution of the north-western continental Greece. Geol. Rundsch., 76/2, Stuttgart. pp. 433-450.

Doutsos, T., Kontopoulos, N., Poulimenos, G. 1988. The Corinth - Patras rift as the initial stage of continental fragmentation behind an active island arc (Greece). Basin Research, 1, pp.177-190.

IGME, 1971. Geological map of Greece at a scale of 1:50,000, "Nafpactos sheet".Athens.

IGME, 1980. Geological map of Greece at a scale of 1:50,000, "Patras sheet".Athens. 
IGME, 1984. Geological map of Greece at a scale of 1:50,000, “Chalandritsa sheet”.Athens.

Kontopoulos, N., Zelilidis, A. 1992. Upper Pliocene lacustrine environments in the intramontane Rio graben basin, NW Peloponnesus, Greece. N.Jb.Geol.Paläont.Mh., H.2,Stuttgart, pp.102-114.

Kontopoulos, N., Zelilidis, A. 1997. Depositional environments of the coarse-grained lower Pleistocene deposits in the Rio - Antirio basin, Greece. Proc. Int. Symposium on Engineering Geology and the Environment, IAEG, Athens. vol.1, Balkema, Rotterdam.

Kouki A. 2006. Engineering geological - geotechnical parameters and mechanical behavior of hard soils and soft rocks in the design of underground works. PhD Thesis. In Greek, with extensive summary in English. University of Patras, p.414.

Koukis, G., Rozos, D., 1990. Geotechnical properties of Neogene sediments of the NW Peloponnesus Greece. Proc 6th Int. IAEG Congress, Amsterdam p405-412. Balkema, Rotterdam.

Koukis, G., Sabatakakis, N., Tsiambaos, G. and Katrivesis, N., 2005. Engineering geological approach to the evaluation of seismic risk in metropolitan regions: case study of Patras, Greece. Bulletin of Eng. Geol. and Environment, 64: p 219-235.

Koukis,G., Sabatakakis, N., Lainas, S., 2007. Soil suitability estimation for housing purposes in landslide - prone areas. The case of Karya village, Patras, W. Greece. Bulletin of the Geological Society of Greece, Proc. $11^{\text {th }}$ Int. Congr., vol. xxx, 1683-1694.

National Meteorological Service, 2004. Climate data from Patra's station for the period of 1931-2004, Athens.

NEAK, 2004. New Hellenic Anti-Seismic Code, Athens.

Rozos, D. 1998. Engineering Geological conditions in Achaia County. Geomechanical characteristics of Plio-Pleistocene sediments. PhD Thesis (in Greek, with extensive summary in English). University of Patras, 453p. Rio Patras.

Rozos, D., Koukis, G., Sabatakakis, N., 2006. Large scale engineering geological map of the Patras city wider area, Greece. The Geological Society of London, IAEG 2006, paper no 241.

Sokos, E. 1998. Strong ground motion synthesis at the city of Patras. PhD Thesis, University of Patras.

Tsiambaos, G., Sabatakakis, N., Koukis, G., 1997. Engineering geological environment and urban planning of the city of Patras, Greece. Proceedings of the Int. Symp. of Eng. Geology and the Environment, Athens, 23-27 June, vol. 3:1527-1534.

Voudouris, K. 1995. Hydrogeological conditions of the NW part of Achaia Province. PhD Thesis, University of Patras. 